Supplement of

\title{
Variations and sources of volatile organic compounds (VOCs) in urban region: insights from measurements on a tall tower
}

Xiao-Bing $\mathrm{Li}^{1,2}$, Bin Yuan ${ }^{1,2, *}$, Sihang Wang ${ }^{1,2}$, Chunlin Wang ${ }^{3,4}$, Jing Lan ${ }^{3,4}$, Zhijie $\mathrm{Liu}^{1,2}$, Yongxin Song ${ }^{1,2}$, Xianjun $\mathrm{He}^{1,2}$, Yibo Huangfu ${ }^{1,2}$, Chenglei Pei ${ }^{5,6,7,8}$, Peng

Cheng ${ }^{9}$, Suxia Yang ${ }^{1,2}$, Jipeng $\mathrm{Qi}^{1,2}$, Caihong Wu ${ }^{1,2}$, Shan Huang ${ }^{1,2}$, Yingchang You ${ }^{1,2}$, Ming Chang ${ }^{1,2}$, Huadan Zheng ${ }^{10}$, Wenda Yang ${ }^{9}$, Xuemei Wang ${ }^{1,2}$, and Min Shao ${ }^{1,2}$

${ }^{1}$ Institute for Environmental and Climate Research, Jinan University, Guangzhou 511443, China

${ }^{2}$ Guangdong-Hongkong-Macau Joint Laboratory of Collaborative Innovation for Environmental Quality, Guangzhou 511443, China

${ }^{3}$ Guangzhou Climate and Agrometeorology Center, Guangzhou, 511430, China

${ }^{4}$ Southern Marine Science and Engineering Guangdong Laboratory (Zhuhai), Zhuhai, 519082, China

${ }^{5}$ State Key Laboratory of Organic Geochemistry and Guangdong Key Laboratory of Environmental Protection and Resources Utilization, Guangzhou Institute of Geochemistry, Chinese Academy of Sciences, Guangzhou 510640, China

${ }^{6}$ CAS Center for Excellence in Deep Earth Science, Guangzhou, 510640, China

${ }^{7}$ University of Chinese Academy of Sciences, Beijing 100049, China

${ }^{8}$ Guangzhou Ecological and Environmental Monitoring Center of Guangdong Province, Guangzhou 510060, China

${ }^{9}$ Institute of Mass Spectrometer and Atmospheric Environment, Jinan University, Guangzhou 510632, Guangdong, China

10 Guangdong Provincial Key Laboratory of Optical Fiber Sensing and Communications, and Department of Optoelectronic Engineering, Jinan University, Guangzhou, 510632, China

*Corresponding authors: byuan@j,jnu.edu.cn 
Table S1. Average mixing ratio, limits of detection (LOD), and instrument sensitivity for the VOC species reported in this study.

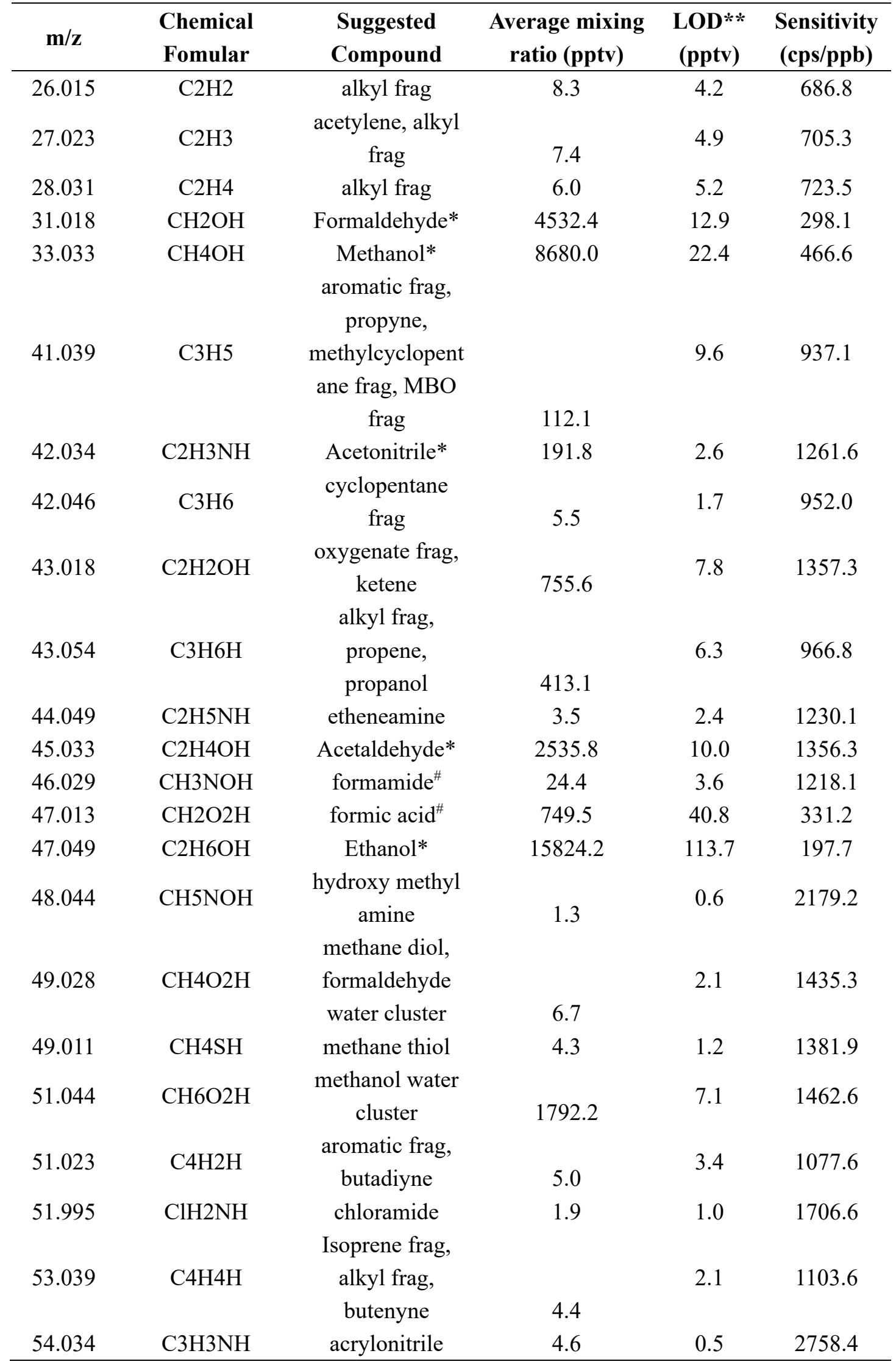




\begin{tabular}{|c|c|c|c|c|c|}
\hline 57.033 & $\mathrm{C} 3 \mathrm{H} 4 \mathrm{OH}$ & Acrolein* & 192.2 & 13.2 & 1691.7 \\
\hline 57.070 & C4H9 & $\begin{array}{l}\text { butenes, alkyl } \\
\text { frag, butanol }\end{array}$ & 798.2 & 1.0 & 1204.8 \\
\hline 58.029 & $\mathrm{C} 2 \mathrm{H} 3 \mathrm{NOH}$ & $\begin{array}{c}\text { methyl } \\
\text { isocyanate, } \\
\text { hydroxy } \\
\text { acetonitrile }\end{array}$ & 6.0 & 0.8 & 2103.9 \\
\hline 59.049 & $\mathrm{C} 3 \mathrm{H} 6 \mathrm{OH}$ & Acetone* & 4386.8 & 6.7 & 1755.1 \\
\hline 60.044 & $\mathrm{C} 2 \mathrm{H} 5 \mathrm{NOH}$ & acetamide $^{\#}$ & 42.1 & 2.9 & 1693.6 \\
\hline 61.028 & $\mathrm{C} 2 \mathrm{H} 4 \mathrm{O} 2 \mathrm{H}$ & Acetic acid & 4792.9 & 34.8 & 661.5 \\
\hline 62.024 & $\mathrm{CH} 3 \mathrm{NO} 2 \mathrm{H}$ & $\begin{array}{l}\text { nitromethane } \\
\text { ethane diols, } \\
\text { acetaldehyde }\end{array}$ & 10.2 & 1.3 & 2520.9 \\
\hline 63.044 & $\mathrm{C} 2 \mathrm{H} 6 \mathrm{O} 2 \mathrm{H}$ & $\begin{array}{c}\text { water cluster, } \\
\text { ethyl }\end{array}$ & & 5.1 & 1522.0 \\
\hline & & $\begin{array}{l}\text { hydroperoxide, } \\
\text { ethylene glycol } \\
\text { formic acid }\end{array}$ & 366.1 & & \\
\hline 65.023 & $\mathrm{CH} 4 \mathrm{O} 3 \mathrm{H}$ & water cluster & 57.7 & 3.5 & 1804.9 \\
\hline 65.060 & $\mathrm{C} 2 \mathrm{H} 8 \mathrm{O} 2 \mathrm{H}$ & $\begin{array}{l}\text { ethanol water } \\
\text { cluster }\end{array}$ & 1246.2 & 34.8 & 1605.2 \\
\hline 67.039 & $\mathrm{CH} 7 \mathrm{O} 3$ & $\begin{array}{l}\text { methane diol } \\
\text { water cluster }\end{array}$ & 2.1 & 0.7 & 1821.4 \\
\hline 67.054 & $\mathrm{C} 5 \mathrm{H} 6 \mathrm{H}$ & $\begin{array}{c}\text { cyclopentadiene, } \\
\text { monoterpene } \\
\text { frag }\end{array}$ & 11.3 & 2.1 & 1267.6 \\
\hline 68.049 & $\mathrm{C} 4 \mathrm{H} 5 \mathrm{NH}$ & pyrrole $^{\#}$ & 4.3 & 1.3 & 1205.7 \\
\hline 68.062 & $\mathrm{C} 5 \mathrm{H} 8$ & alkyl frag & 4.7 & 1.4 & 1278.2 \\
\hline 69.055 & $\mathrm{CH} 8 \mathrm{O} 3 \mathrm{H}$ & $\begin{array}{l}\text { methanol }+2 \\
\text { water cluster }\end{array}$ & 26.9 & 1.4 & 1836.9 \\
\hline 69.033 & $\mathrm{C} 4 \mathrm{H} 4 \mathrm{OH}$ & Fural* & 30.5 & 3.6 & 1194.0 \\
\hline 69.070 & $\mathrm{C} 5 \mathrm{H} 8 \mathrm{H}$ & Isoprene* & 293.7 & 4.5 & 1068.7 \\
\hline 70.065 & $\mathrm{C} 4 \mathrm{H} 7 \mathrm{NH}$ & butane nitrile & 11.6 & 1.0 & 2756.5 \\
\hline 71.049 & $\mathrm{C} 4 \mathrm{H} 6 \mathrm{OH}$ & $\begin{array}{c}\text { Methy Vinyl } \\
\text { Ketone* }\end{array}$ & 316.5 & 3.7 & 1919.5 \\
\hline 71.086 & $\mathrm{C} 5 \mathrm{H} 10 \mathrm{H}$ & $\begin{array}{c}\text { pentenes, alkyl } \\
\text { frag, C2 and C3 } \\
\text { cyclhexanes }\end{array}$ & 271.6 & 3.9 & 1308.1 \\
\hline 72.044 & $\mathrm{C} 3 \mathrm{H} 5 \mathrm{NOH}$ & $\begin{array}{l}\text { ethyl isocyanate, } \\
\text { Methoxyacetoni } \\
\text { trile, acrylamide }\end{array}$ & 4.8 & 0.9 & 3113.7 \\
\hline 72.057 & $\mathrm{C} 4 \mathrm{H} 8 \mathrm{O}$ & $\begin{array}{l}\text { C4 carbonyl } \\
\mathrm{O} 2+\text { product }\end{array}$ & 11.8 & 1.3 & 1552.1 \\
\hline 73.028 & $\mathrm{C} 3 \mathrm{H} 4 \mathrm{O} 2 \mathrm{H}$ & methyl glyoxal, & 57.7 & 2.4 & 1713.7 \\
\hline
\end{tabular}




\begin{tabular}{|c|c|c|c|c|c|}
\hline & & $\begin{array}{l}\text { acrylic acid } \\
2-\end{array}$ & & & \\
\hline \multirow[t]{2}{*}{73.065} & $\mathrm{C} 4 \mathrm{H} 8 \mathrm{OH}$ & Butanone/Methy & & 9.4 & 1938.2 \\
\hline & & 1 Ethyl Ketone* & 1183.9 & & \\
\hline 73.101 & $\mathrm{C} 5 \mathrm{H} 12 \mathrm{H}$ & $\begin{array}{l}\text { pentanes (esp } \\
\text { isopentane) }\end{array}$ & 13.3 & 1.5 & 1329.2 \\
\hline \multirow[t]{2}{*}{74.060} & \multirow[t]{2}{*}{$\mathrm{C} 3 \mathrm{H} 7 \mathrm{NOH}$} & $\mathrm{C} 3$ amides & 177.2 & \multirow[t]{2}{*}{2.1} & \multirow[t]{2}{*}{2708.0} \\
\hline & & $\begin{array}{l}\text { Hydroxyacetone } \\
\text { *, propionic }\end{array}$ & & & \\
\hline \multirow[t]{2}{*}{75.044} & \multirow[t]{2}{*}{$\mathrm{C} 3 \mathrm{H} 6 \mathrm{O} 2 \mathrm{H}$} & $\begin{array}{l}\text { acid, methyl } \\
\text { acetate, ethyl }\end{array}$ & & \multirow[t]{2}{*}{14.6} & \multirow[t]{2}{*}{1234.8} \\
\hline & & formate & 2288.1 & & \\
\hline \multirow[t]{2}{*}{75.080} & \multirow[t]{2}{*}{$\mathrm{C} 4 \mathrm{H} 10 \mathrm{OH}$} & $\begin{array}{c}\text { butanols, } \\
\text { monoterpene } \\
\text { oxidation }\end{array}$ & & \multirow[t]{2}{*}{2.0} & \multirow[t]{2}{*}{1569.0} \\
\hline & & product & 23.4 & & \\
\hline 76.039 & $\mathrm{C} 2 \mathrm{H} 5 \mathrm{NO} 2 \mathrm{H}$ & nitroethane & 7.4 & 1.4 & 2439.2 \\
\hline & & $\begin{array}{l}\text { hydroxy or } \\
\text { peroxyacetic }\end{array}$ & & & \\
\hline \multirow[t]{2}{*}{77.023} & \multirow[t]{2}{*}{$\mathrm{C} 2 \mathrm{H} 4 \mathrm{O} 3 \mathrm{H}$} & acid (PAN & & \multirow[t]{2}{*}{2.9} & \multirow[t]{2}{*}{1972.0} \\
\hline & & $\begin{array}{l}\text { indicator), } \\
\text { glycolic acid } \\
\text { acetone water }\end{array}$ & 148.7 & & \\
\hline 77.060 & $\mathrm{C} 3 \mathrm{H} 8 \mathrm{O} 2 \mathrm{H}$ & $\begin{array}{c}\text { cluster, C3 } \\
\text { hydroperoxide, } \\
\text { propane diols }\end{array}$ & 200.4 & 3.0 & 1678.6 \\
\hline 77.039 & $\mathrm{C} 6 \mathrm{H} 5$ & aromatic frag & 3.7 & 1.5 & 1367.5 \\
\hline 78.046 & C6H6 & $\begin{array}{l}\text { benzene charge } \\
\text { transfer }\end{array}$ & 8.8 & 1.2 & 1376.8 \\
\hline 79.039 & $\mathrm{C} 2 \mathrm{H} 6 \mathrm{O} 3 \mathrm{H}$ & $\begin{array}{c}\text { acetic acid water } \\
\text { cluster }\end{array}$ & 277.2 & 5.8 & 1901.2 \\
\hline 79.075 & $\mathrm{C} 3 \mathrm{H} 10 \mathrm{O} 2 \mathrm{H}$ & $\begin{array}{c}\text { propanol water } \\
\text { cluster }\end{array}$ & 24.6 & 1.1 & 1688.0 \\
\hline 79.054 & C6H6H & Benzene* & 384.7 & 3.4 & 1235.1 \\
\hline 80.034 & $\mathrm{CH} 5 \mathrm{NO} 3 \mathrm{H}$ & $\begin{array}{l}\text { trihydroxy } \\
\text { methyl amine }\end{array}$ & 10.0 & 2.1 & 1394.9 \\
\hline 80.990 & $\mathrm{C} 2 \mathrm{H} 2 \mathrm{FClH}$ & $\begin{array}{c}\text { chlorofluoroethe } \\
\text { ne }\end{array}$ & 23.4 & 1.0 & 1403.8 \\
\hline 81.055 & $\mathrm{C} 2 \mathrm{H} 8 \mathrm{O} 3 \mathrm{H}$ & $\begin{array}{c}\text { ethane diol } \\
\text { water cluster }\end{array}$ & 12.1 & 1.7 & 1911.7 \\
\hline 81.033 & $\mathrm{C} 5 \mathrm{H} 4 \mathrm{OH}$ & $\begin{array}{l}\text { cyclopentadiene } \\
\text { ketone }\end{array}$ & 4.5 & 2.1 & 2483.4 \\
\hline 81.070 & $\mathrm{C} 6 \mathrm{H} 8 \mathrm{H}$ & $\begin{array}{c}\text { monoterpene } \\
\text { frag, }\end{array}$ & 97.6 & 2.7 & 1403.9 \\
\hline
\end{tabular}




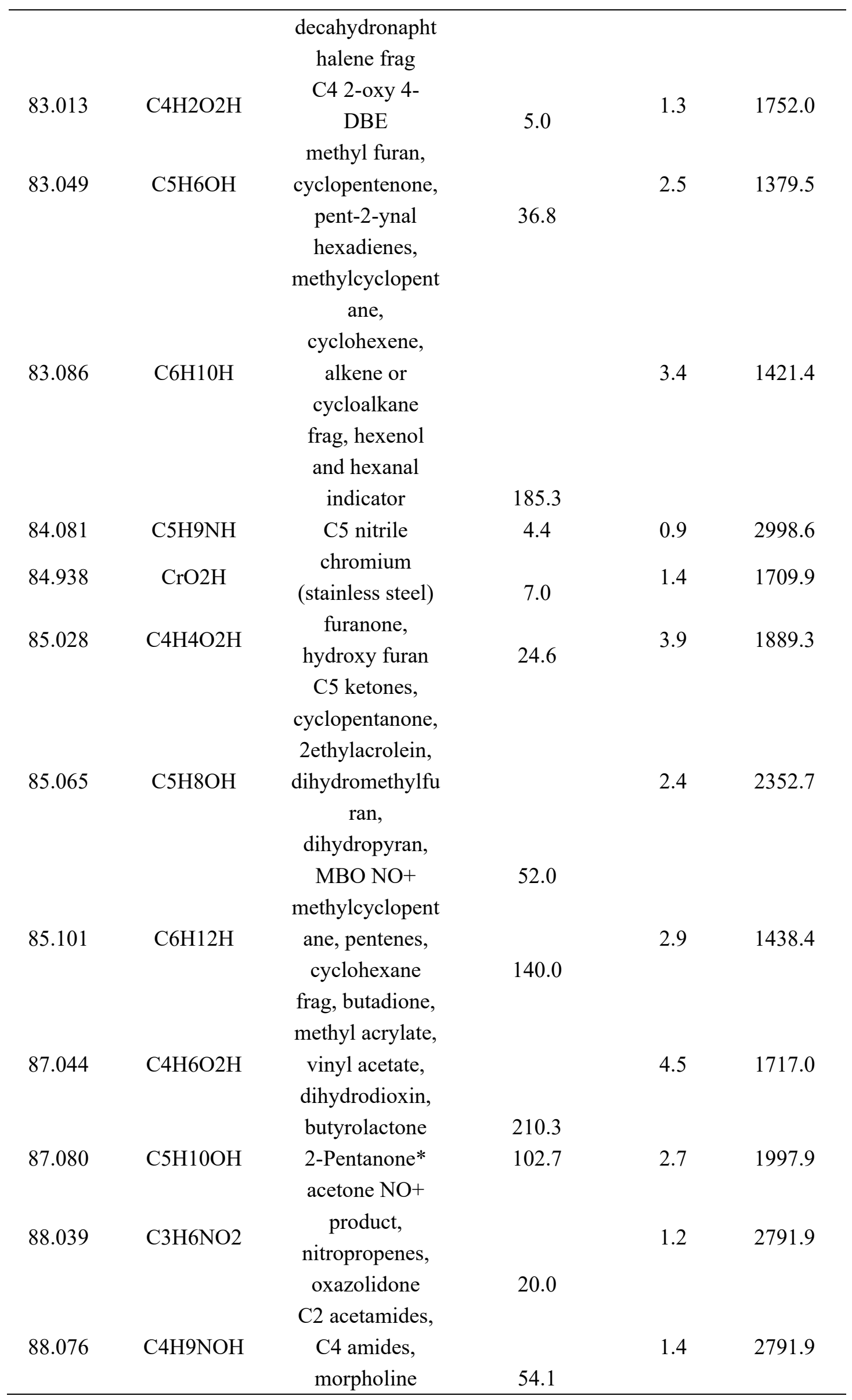




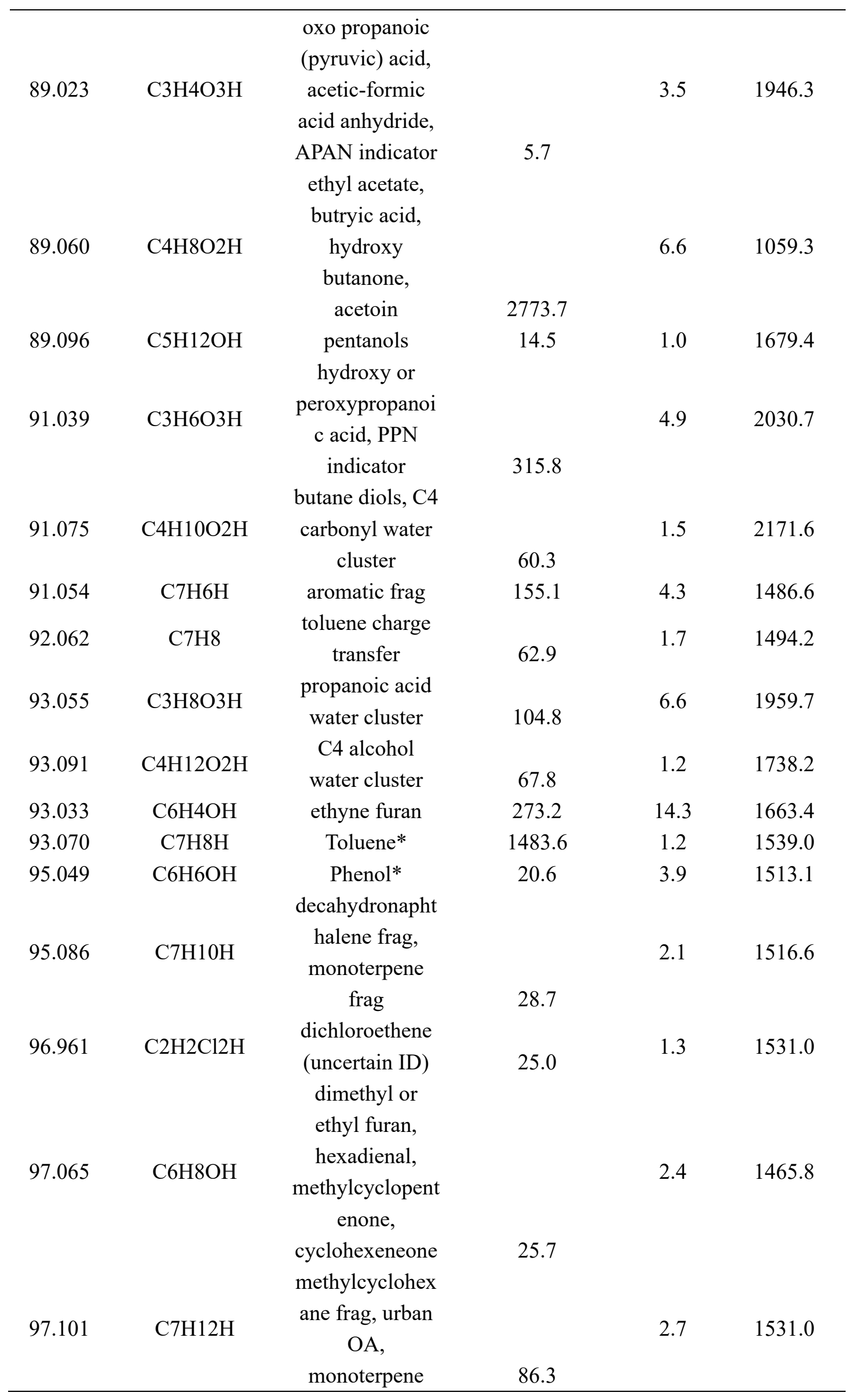




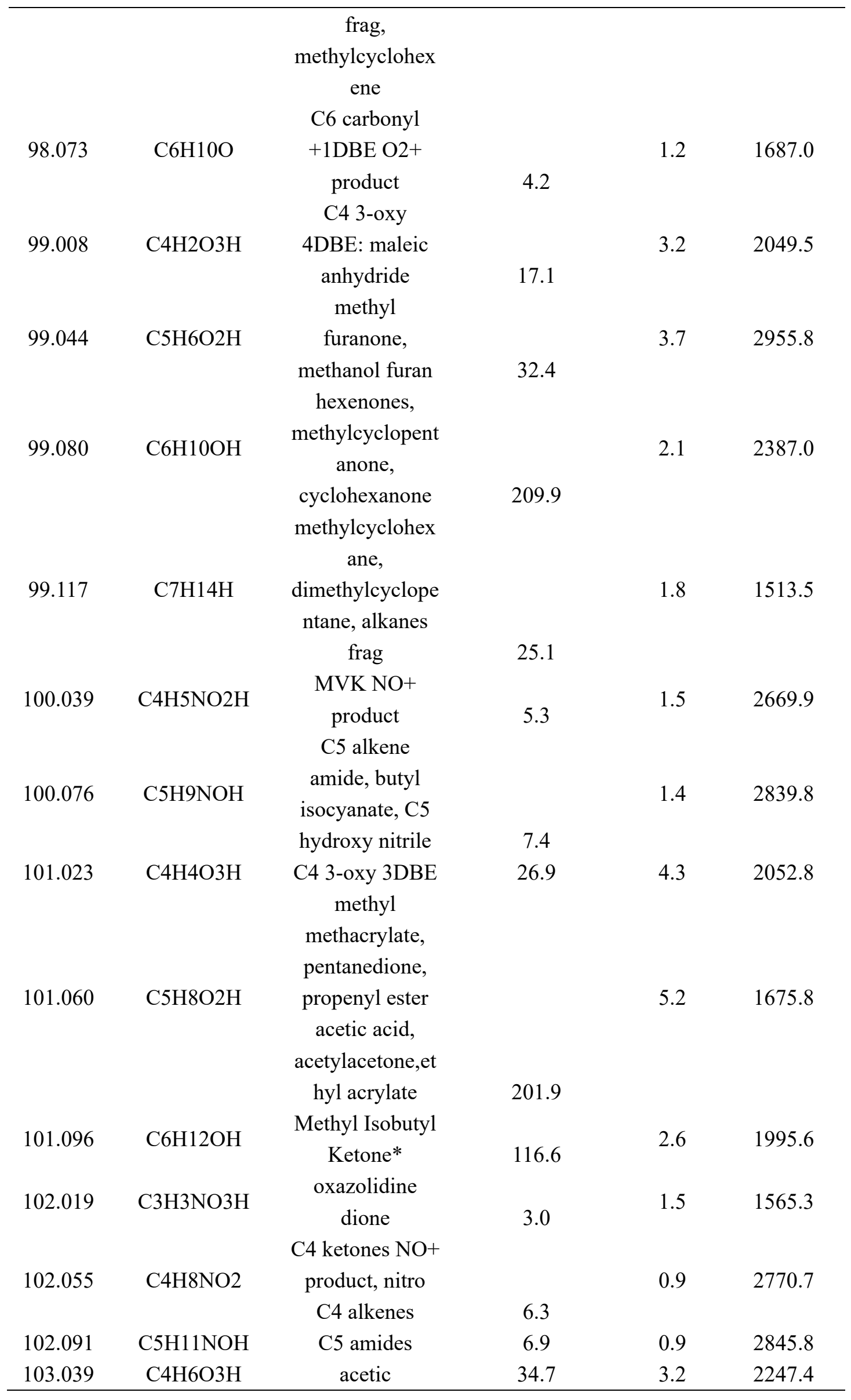




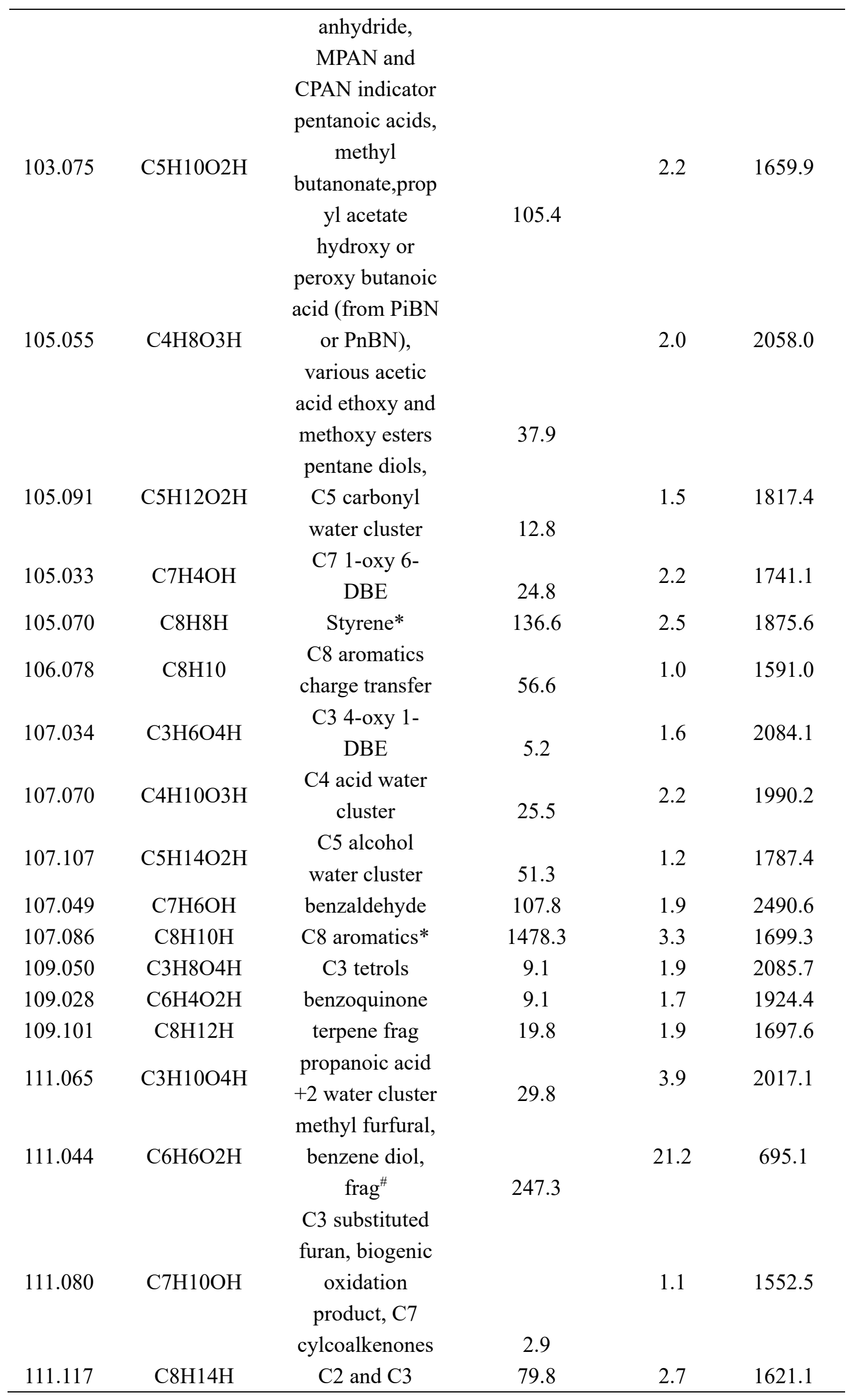




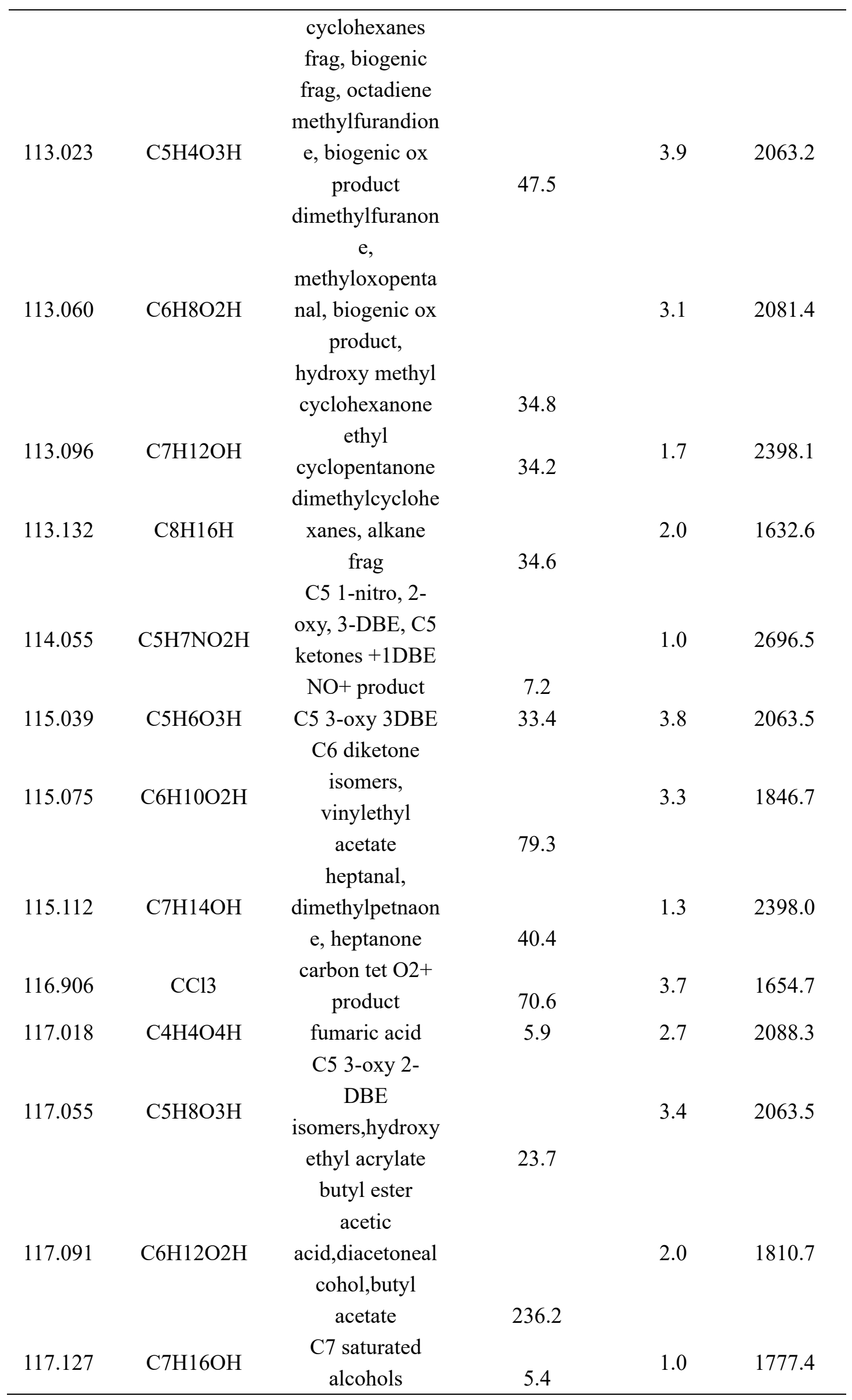




\begin{tabular}{|c|c|c|c|c|c|}
\hline 118.050 & $\mathrm{C} 4 \mathrm{H} 7 \mathrm{NO} 3 \mathrm{H}$ & butene nitrates & 8.5 & 1.8 & 1659.8 \\
\hline 119.034 & $\mathrm{C} 4 \mathrm{H} 6 \mathrm{O} 4 \mathrm{H}$ & $\begin{array}{l}\text { butane dioic } \\
\text { acid }\end{array}$ & 10.2 & 3.1 & 2088.1 \\
\hline 119.107 & $\mathrm{C} 6 \mathrm{H} 14 \mathrm{O} 2 \mathrm{H}$ & $\begin{array}{l}\text { C6 saturated } \\
\text { diols, C6 } \\
\text { carbonyl water } \\
\text { cluster,butoxy } \\
\text { ethanol }\end{array}$ & 104.1 & 1.9 & 1826.1 \\
\hline 119.089 & C6H14SH & $\begin{array}{l}\text { C6 } \\
\text { thiols/sulfides }\end{array}$ & 6.3 & 1.3 & 1780.2 \\
\hline 120.093 & С9H12 & $\begin{array}{l}\text { C9 aromatics } \\
\text { charge transfer }\end{array}$ & 7.1 & 0.8 & 1670.1 \\
\hline 121.065 & $\mathrm{C} 8 \mathrm{H} 8 \mathrm{OH}$ & $\begin{array}{l}\text { tolualdehyde, } \\
\text { acetophenone, } \\
\text { dihydrobenzofur } \\
\text { an, vinylphenol, } \\
\text { benzeneacetalde } \\
\text { hyde }\end{array}$ & 64.5 & 1.8 & 2395.6 \\
\hline 121.101 & $\mathrm{C} 9 \mathrm{H} 12 \mathrm{H}$ & C9 aromatics* & 231.8 & 2.7 & 1800.9 \\
\hline 122.008 & $\mathrm{C} 2 \mathrm{H} 3 \mathrm{NO} 5 \mathrm{H}$ & $\begin{array}{l}\mathrm{C} 2 \mathrm{H} 3 \mathrm{NO} 5 \mathrm{H}+ \\
\text { salicyladehyde, }\end{array}$ & 13.2 & 1.9 & 1680.3 \\
\hline 123.044 & $\mathrm{C} 7 \mathrm{H} 6 \mathrm{O} 2 \mathrm{H}$ & $\begin{array}{l}\text { benzodioxole, } \\
\text { benzoic acid }\end{array}$ & 17.8 & 2.5 & 2382.2 \\
\hline 123.080 & $\mathrm{C} 8 \mathrm{H} 10 \mathrm{OH}$ & $\begin{array}{l}\text { 4-ethylphenol, } \\
\text { dimethylphenol, } \\
\text { methylanisole }\end{array}$ & 4.1 & 1.1 & 1797.4 \\
\hline 123.117 & $\mathrm{C} 9 \mathrm{H} 14 \mathrm{H}$ & $\begin{array}{l}\text { terpene frag, } \\
\text { santene }\end{array}$ & 18.7 & 1.8 & 1685.0 \\
\hline 124.039 & C6H5NO2H & nitrobenzene & 2.8 & 1.1 & 3081.4 \\
\hline 125.060 & $\mathrm{C} 7 \mathrm{H} 8 \mathrm{O} 2 \mathrm{H}$ & Guaiacol* & 10.9 & 3.0 & 2670.7 \\
\hline 125.132 & C9H16H & $\begin{array}{l}\text { trimethylcycloh } \\
\text { exane frag }\end{array}$ & 51.2 & 2.2 & 1694.6 \\
\hline 127.075 & $\mathrm{C} 7 \mathrm{H} 10 \mathrm{O} 2 \mathrm{H}$ & furanone & 20.4 & 3.0 & 1878.7 \\
\hline 127.112 & $\mathrm{C} 8 \mathrm{H} 14 \mathrm{OH}$ & cyclooctanone & 30.6 & 1.7 & 2390.3 \\
\hline 127.148 & $\mathrm{C} 9 \mathrm{H} 18 \mathrm{H}$ & $\begin{array}{l}\text { trimethylcycloh } \\
\text { exane }\end{array}$ & 12.1 & 1.7 & 1703.9 \\
\hline 129.055 & $\mathrm{C} 6 \mathrm{H} 8 \mathrm{O} 3 \mathrm{H}$ & $\begin{array}{l}\text { methyloxopente } \\
\text { noic acid, } \\
\text { acetylmethyloxi } \\
\text { ranecarbaldehyd }\end{array}$ & & 3.0 & 2057.5 \\
\hline & & $\begin{array}{c}\mathrm{e} \\
\text { allyl ester }\end{array}$ & 20.9 & & \\
\hline 129.091 & $\mathrm{C} 7 \mathrm{H} 12 \mathrm{O} 2 \mathrm{H}$ & $\begin{array}{l}\text { isobutyric } \\
\text { acid,butyl }\end{array}$ & 40.4 & 2.7 & 1846.4 \\
\hline
\end{tabular}




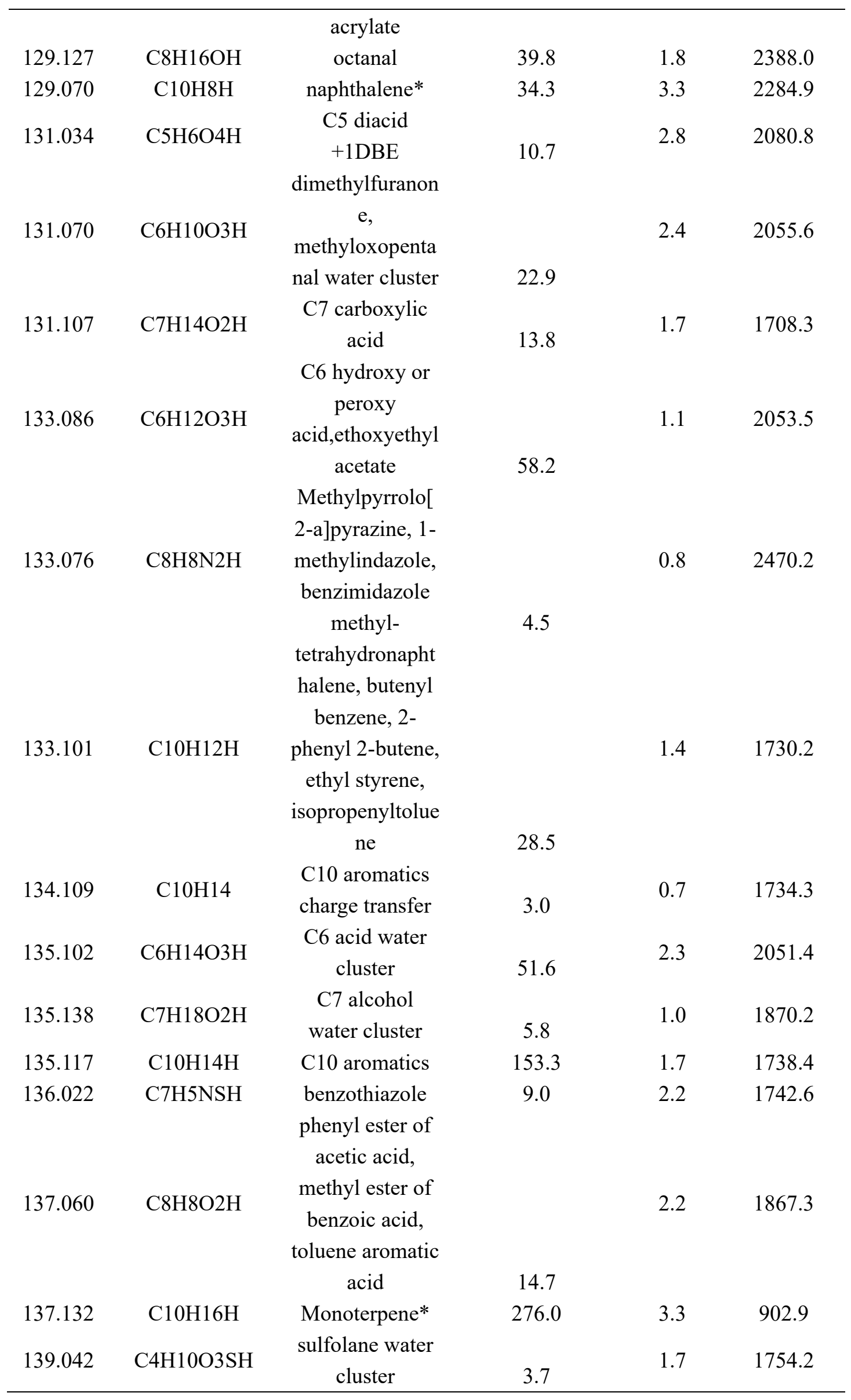




\begin{tabular}{|c|c|c|c|c|c|}
\hline 139.039 & $\mathrm{C} 7 \mathrm{H} 6 \mathrm{O} 3 \mathrm{H}$ & $\begin{array}{l}\text { salicylic acid, } \\
\text { biogenic ox } \\
\text { product, PBzN } \\
\text { indicator }\end{array}$ & 5.9 & 1.4 & 2047.6 \\
\hline 139.112 & $\mathrm{C} 9 \mathrm{H} 14 \mathrm{OH}$ & $\begin{array}{c}\text { nopinone, C5 } \\
\text { substituted furan }\end{array}$ & 38.3 & 1.5 & 2373.4 \\
\hline 139.148 & $\mathrm{C} 10 \mathrm{H} 18 \mathrm{H}$ & $\begin{array}{l}\text { C10 1DBE } \\
\text { hydride } \\
\text { abstraction }\end{array}$ & 24.8 & 1.8 & 1754.0 \\
\hline 140.034 & C6H5NO3H & $\begin{array}{c}\text { benzene } \\
\text { nitrophenol, } \\
\text { benzene nitrate }^{\#}\end{array}$ & 15.4 & 5.4 & 1526.2 \\
\hline 141.127 & $\mathrm{C} 9 \mathrm{H} 16 \mathrm{OH}$ & $\begin{array}{c}\text { C9 carbonyl } \\
+1 \mathrm{DBE}, \mathrm{C} 9 \\
\text { alcohol }+2 \mathrm{DBE}\end{array}$ & 15.7 & 1.3 & 2370.2 \\
\hline 141.164 & $\mathrm{C} 10 \mathrm{H} 20 \mathrm{H}$ & $\begin{array}{c}\text { C10 1DBE, C10 } \\
\text { alkanes hydride } \\
\text { abstraction }\end{array}$ & 9.6 & 1.6 & 1761.5 \\
\hline 143.107 & $\mathrm{C} 8 \mathrm{H} 14 \mathrm{O} 2 \mathrm{H}$ & $\begin{array}{c}\text { C8 2-oxy 2DBE } \\
\text { isomers }\end{array}$ & 23.3 & 2.3 & 1914.4 \\
\hline 143.143 & $\mathrm{C} 9 \mathrm{H} 18 \mathrm{OH}$ & nonanal & 87.7 & 2.0 & 2367.0 \\
\hline 145.122 & $\mathrm{C} 8 \mathrm{H} 16 \mathrm{O} 2 \mathrm{H}$ & $\begin{array}{c}\text { C8 carboxylic } \\
\text { acid }\end{array}$ & 22.5 & 1.9 & 1714.5 \\
\hline 149.117 & C7H16O3H & $\begin{array}{l}\text { C7 acid water } \\
\text { cluster }\end{array}$ & 19.4 & 1.4 & 1989.5 \\
\hline 149.132 & $\mathrm{C} 11 \mathrm{H} 16 \mathrm{H}$ & $\begin{array}{l}\text { C11 aromatics } \\
\text { pinonaldehyde, }\end{array}$ & 26.4 & 1.2 & 1789.1 \\
\hline 151.112 & $\mathrm{C} 10 \mathrm{H} 14 \mathrm{OH}$ & $\begin{array}{l}\text { C10 aromatic } \\
\text { alcohols }\end{array}$ & 13.8 & 1.4 & 2004.7 \\
\hline 151.148 & $\mathrm{C} 11 \mathrm{H} 18 \mathrm{H}$ & $\begin{array}{l}\text { C11 3-DBE } \\
\text { methyl }\end{array}$ & 14.4 & 1.5 & 1795.5 \\
\hline 153.055 & $\mathrm{C} 8 \mathrm{H} 8 \mathrm{O} 3 \mathrm{H}$ & $\begin{array}{c}\text { salicylate, C8 } \\
\text { aromatic }\end{array}$ & & 1.5 & 2034.5 \\
\hline 153.127 & $\mathrm{C} 10 \mathrm{H} 16 \mathrm{OH}$ & $\begin{array}{l}\text { hydroxyacid } \\
\text { apinene oxide, } \\
\text { camphor, C6 } \\
\text { substituted } \\
\text { furans }\end{array}$ & 23.8 & 1.7 & 1959.9 \\
\hline 153.164 & $\mathrm{C} 11 \mathrm{H} 20 \mathrm{H}$ & $\begin{array}{c}\text { C11 2-DBE } \\
\text { linalool, }\end{array}$ & 11.6 & 1.5 & 1801.6 \\
\hline 155.143 & $\mathrm{C} 10 \mathrm{H} 18 \mathrm{OH}$ & $\begin{array}{l}\text { borneol,terpilen } \\
\text { ol }\end{array}$ & 14.5 & 1.8 & 1876.6 \\
\hline 155.179 & $\mathrm{C} 11 \mathrm{H} 22 \mathrm{H}$ & $\begin{array}{l}\text { C11 1-DBE, } \\
\text { C11 alkanes }\end{array}$ & 8.2 & 1.4 & 1807.5 \\
\hline
\end{tabular}




\begin{tabular}{|c|c|c|c|c|c|}
\hline & & $\mathrm{NO}+$ product & & & \\
\hline 157.159 & $\mathrm{C} 10 \mathrm{H} 20 \mathrm{OH}$ & $\begin{array}{l}\text { Menthol-type } \\
\text { monoterpenes, } \\
\text { decanal }\end{array}$ & 38.0 & 2.5 & 1871.0 \\
\hline 161.081 & $\mathrm{C} 7 \mathrm{H} 12 \mathrm{O} 4 \mathrm{H}$ & C7 di-acids & 9.8 & 1.6 & 2047.7 \\
\hline 161.154 & $\mathrm{C} 9 \mathrm{H} 20 \mathrm{O} 2 \mathrm{H}$ & $\begin{array}{l}\text { C9 saturated } \\
\text { diols, C9 } \\
\text { carbonyl water } \\
\text { cluster }\end{array}$ & 13.1 & 1.3 & 1945.0 \\
\hline 161.132 & $\mathrm{C} 12 \mathrm{H} 16 \mathrm{H}$ & aromatic frag & 3.5 & 0.8 & 1824.3 \\
\hline 163.133 & $\mathrm{C} 8 \mathrm{H} 18 \mathrm{O} 3 \mathrm{H}$ & $\begin{array}{l}\text { C8 acid water } \\
\text { cluster }\end{array}$ & 7.8 & 1.9 & 1981.7 \\
\hline 163.148 & $\mathrm{C} 12 \mathrm{H} 18 \mathrm{H}$ & $\mathrm{C} 12$ aromatics & 7.0 & 1.4 & 1829.4 \\
\hline 165.164 & $\mathrm{C} 12 \mathrm{H} 20 \mathrm{H}$ & C12 3-DBE & 13.1 & 1.5 & 1834.4 \\
\hline 167.179 & $\mathrm{C} 12 \mathrm{H} 22 \mathrm{H}$ & C12 2-DBE & 7.6 & 1.4 & 1839.2 \\
\hline 169.122 & $\mathrm{C} 10 \mathrm{H} 16 \mathrm{O} 2 \mathrm{H}$ & $\begin{array}{l}\text { pinonaldehyde, } \\
\text { apinene } \\
\text { hydroperoxide }\end{array}$ & 17.1 & 2.0 & 1955.8 \\
\hline 169.195 & $\mathrm{C} 12 \mathrm{H} 24 \mathrm{H}$ & $\begin{array}{c}\text { C12 1-DBE, } \\
\text { alkyl frag }\end{array}$ & 10.1 & 1.7 & 1843.8 \\
\hline 171.174 & $\mathrm{C} 11 \mathrm{H} 22 \mathrm{OH}$ & $\begin{array}{c}\text { C11 1-oxy 1- } \\
\text { DBE }\end{array}$ & 10.0 & 1.4 & 1907.1 \\
\hline 178.071 & C6H11NO5H & $\begin{array}{c}\text { C6 1-nitro 5-oxy } \\
\text { 2-DBE }\end{array}$ & 2.4 & 1.0 & 1863.3 \\
\hline 179.179 & $\mathrm{C} 13 \mathrm{H} 22 \mathrm{H}$ & C13 3-DBE & 11.8 & 1.4 & 1864.9 \\
\hline $\begin{array}{c}\mathrm{C} 14 \mathrm{H} 10 \\
\mathrm{H}+\end{array}$ & $\mathrm{C} 14 \mathrm{H} 10 \mathrm{H}$ & $\begin{array}{c}\text { Anthracene or } \\
\text { phenanthrene } \\
\mathrm{H} 3 \mathrm{O}+\end{array}$ & 20.6 & 2.6 & 1888.7 \\
\hline 181.195 & $\mathrm{C} 13 \mathrm{H} 24 \mathrm{H}$ & C13 2-DBE & 6.4 & 1.4 & 1868.6 \\
\hline 183.211 & $\mathrm{C} 13 \mathrm{H} 26 \mathrm{H}$ & & 6.9 & 1.5 & 1872.2 \\
\hline 185.190 & $\mathrm{C} 12 \mathrm{H} 25 \mathrm{O}$ & Dodecanal & 8.8 & 1.6 & 1910.1 \\
\hline 191.179 & $\mathrm{C} 14 \mathrm{H} 22 \mathrm{H}$ & & 8.2 & 2.9 & 1885.4 \\
\hline 193.195 & $\mathrm{C} 14 \mathrm{H} 24 \mathrm{H}$ & & 11.4 & 1.5 & 1888.4 \\
\hline 195.174 & $\mathrm{C} 13 \mathrm{H} 22 \mathrm{OH}$ & Solanone & 2.4 & 1.1 & 1919.0 \\
\hline 195.211 & $\mathrm{C} 14 \mathrm{H} 26 \mathrm{H}$ & & 6.6 & 1.4 & 1891.2 \\
\hline 197.226 & $\mathrm{C} 14 \mathrm{H} 28 \mathrm{H}$ & & 7.3 & 1.6 & 1893.9 \\
\hline 199.169 & $\mathrm{C} 12 \mathrm{H} 22 \mathrm{O} 2 \mathrm{H}$ & Menthyl acetate & 15.4 & 1.6 & 1965.3 \\
\hline 203.179 & $\mathrm{C} 15 \mathrm{H} 22 \mathrm{H}$ & & 5.0 & 1.2 & 1901.7 \\
\hline 205.195 & $\mathrm{C} 15 \mathrm{H} 24 \mathrm{H}$ & & 23.4 & 1.7 & 1904.0 \\
\hline 207.211 & $\mathrm{C} 15 \mathrm{H} 26 \mathrm{H}$ & & 9.8 & 1.3 & 1906.2 \\
\hline 209.226 & $\mathrm{C} 15 \mathrm{H} 28 \mathrm{H}$ & Drimane & 5.8 & 1.3 & 1908.3 \\
\hline 211.242 & $\mathrm{C} 15 \mathrm{H} 30 \mathrm{H}$ & & 6.1 & 1.5 & 1910.3 \\
\hline 215.179 & $\mathrm{C} 16 \mathrm{H} 22 \mathrm{H}$ & & 4.7 & 1.4 & 1914.4 \\
\hline 219.211 & $\mathrm{C} 16 \mathrm{H} 26 \mathrm{H}$ & Perhydropyrene & 6.9 & 1.6 & 1917.8 \\
\hline
\end{tabular}




\begin{tabular}{lccccc}
\hline 221.226 & C16H28H & & 6.4 & 1.2 & 1919.4 \\
223.064 & C6H18O3Si3H & D3 Siloxane* & 70.1 & 7.9 & 1074.9 \\
297.082 & C8H24O4Si4H & D4 Siloxane* & 41.5 & 6.8 & 872.1 \\
299.062 & C7H23O5Si4 & $\begin{array}{c}\text { D5 Siloxane } \\
\text { frag }\end{array}$ & 25.7 & 2.8 & 1948.9 \\
371.101 & C10H30O5Si5H & D5 Siloxane* & 15.1 & 6.7 & 709.5 \\
\hline
\end{tabular}

* Those VOC species are calibrated using the gas standard.

\# Those VOC species are calibrated using the Liquid Calibration Unit (LCU).

$* *$ LOD of VOC species was derived at the initial time resolution of $10 \mathrm{~s}$. 

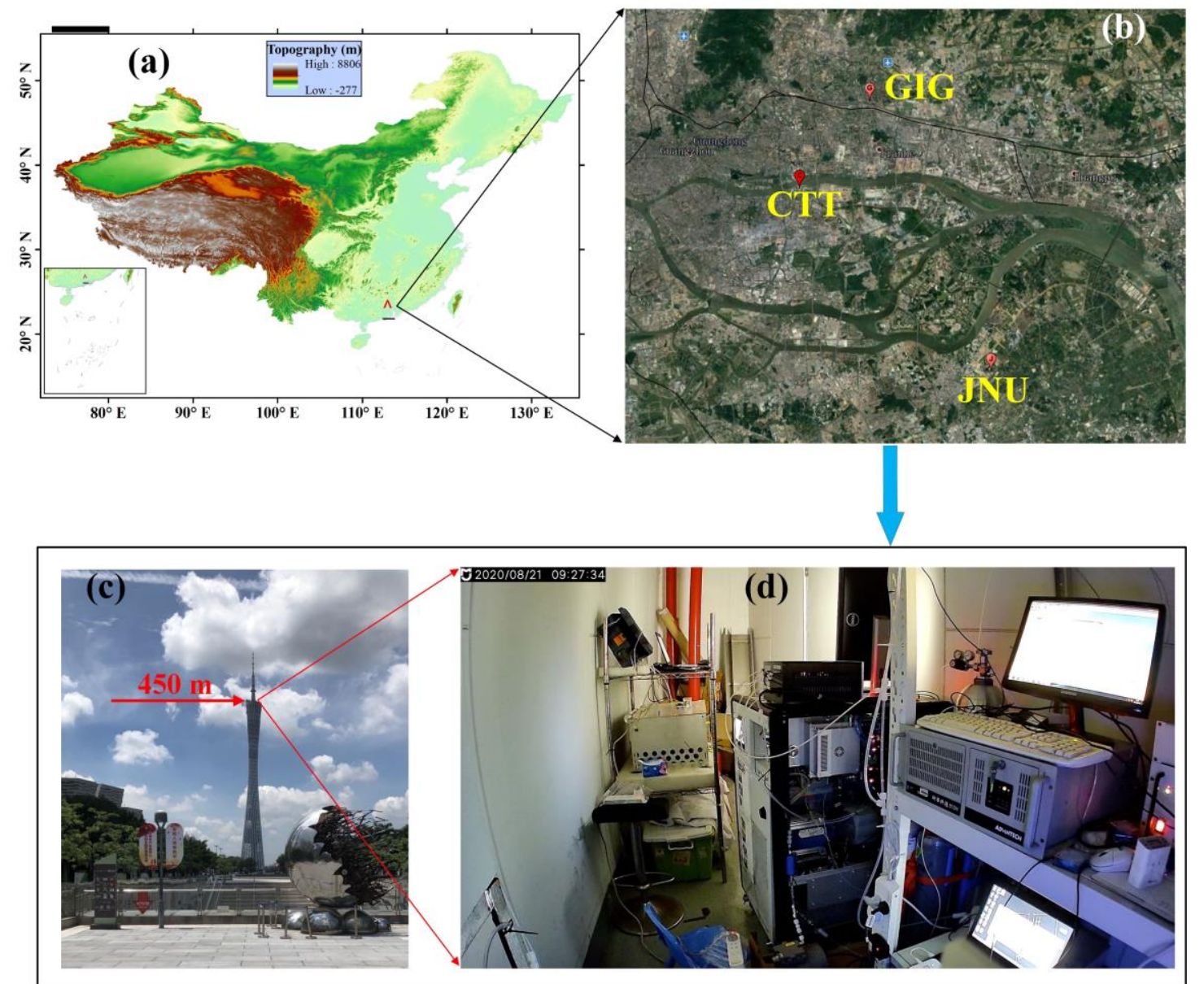

Figure S1. (a) Geographical location of the CTT site in China. (b) Geographical locations of the CTT, GIG, and JNU sites in Guangzhou. (c) Location of the $450 \mathrm{~m}$ Look Out platform on the CTT. (d) Picture of the instruments deployed in the observation room at the $450 \mathrm{~m}$ Look Out platform. Note that the map in panel (b) is extracted from (C) Google Maps by the authors. 

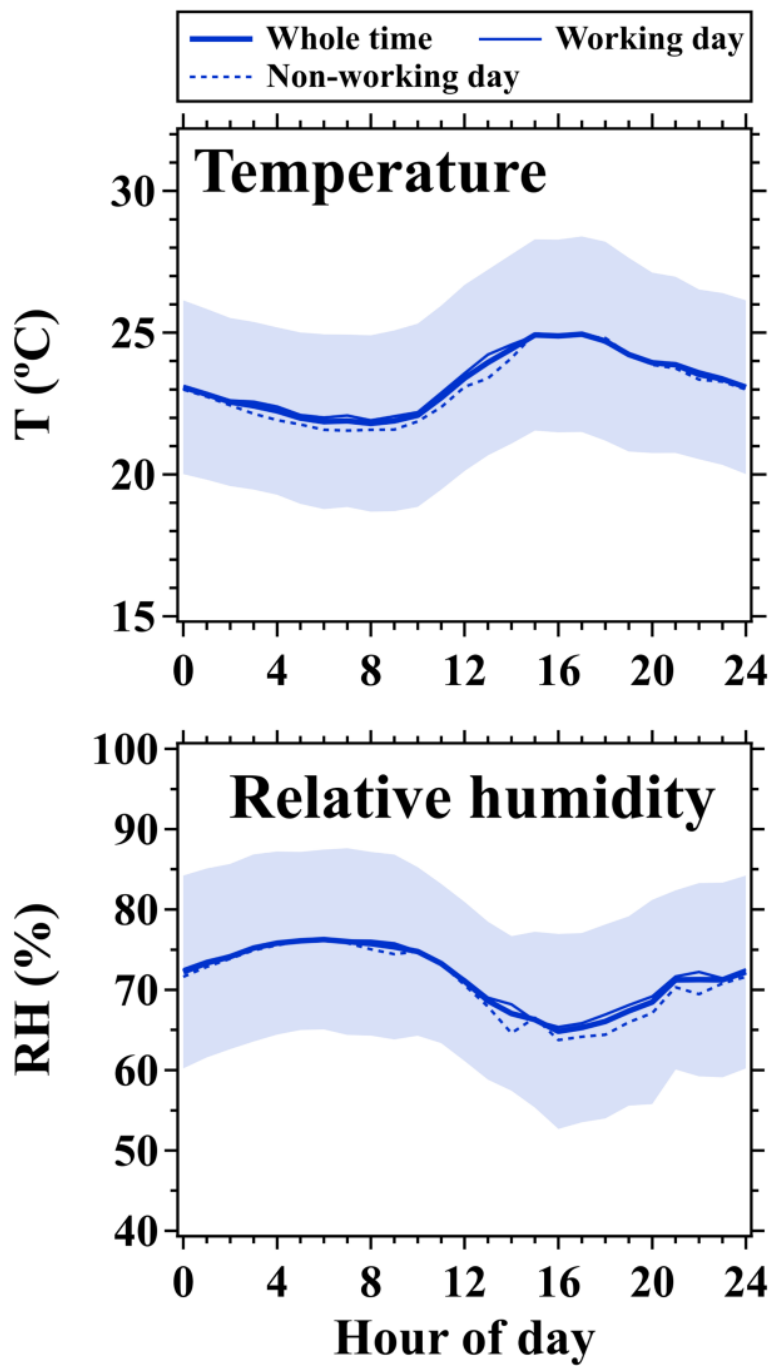

Figure S2. Diurnal variations in temperature $(\mathrm{T})$ and relative humidity $(\mathrm{RH})$ measured at $488 \mathrm{~m}$. Thick blue solid lines and shaded areas represent averages and standard deviations during the CTT campaign (August 18-November 05, 2020); Thin blue solid and dashed lines represent averages on working days and non-working (including weekends and public holidays) days, respectively. 


\section{PMF receptor model}

As expressed in Eq. (S1), the PMF model is a multivariate factor analysis tool that could decompose a data matrix $\boldsymbol{X}$ into two matrices including the source contribution matrix $\boldsymbol{g}$ and the source profile matrix $\boldsymbol{f}$ (Paatero and Tapper, 1994; Paatero et al., 2014).

$$
X_{i j}=\sum_{k=1}^{p} g_{i k} \cdot f_{k j}+e_{i j}
$$

where $i$ is the number of measured samples during the campaign, $j$ is the number of measured chemical species, $p$ is a user-defined number of sources, and $\boldsymbol{e}$ is the residual matrix. The PMF model is solved by minimizing the objective function $Q$ using the measurement uncertainty matrix $\boldsymbol{U}$ and the residual matrix $\boldsymbol{e}$, as expressed in Eq. (S2),

$$
Q=\sum_{i=1}^{n} \sum_{j=1}^{m}\left[\frac{e_{i j}}{U_{i j}}\right]^{2}
$$

where $n$ is the number of measured samples and $j$ is the number of chemical species.

In this study, the 10-min mean mixing ratios of VOC species were used in the PMF model. The measurement uncertainty matrix $\boldsymbol{U}$ could be described in Eq. (S3),

$$
U_{i j}=\sqrt{\left(N S R_{i j} \cdot x_{i j}\right)^{2}+\left(p_{1 j} \cdot x_{i j}\right)^{2}+2 \cdot\left(p_{2} \cdot x_{i j}\right)^{2}+L O D^{2}}
$$

where $N S R_{i j}$ is the $N S R$ for species $j$, as expressed in Eq. (S4); $p_{1 j}$ was assigned to $15 \%$ for the VOC species calibrated by the gas standard and LCU and $50 \%$ for the remaining VOC species; $p_{2}$ is the uncertainty caused by the utilization of mass flow controller (MFC) and was assigned to $1 \%$. In this study, two MFCs were used in the calibration system: one for the gas standard and the other for the zero-air.

$$
N S R_{i j}=\frac{\sqrt{C_{f j} \cdot x_{i j} \cdot t+2 \cdot B \cdot t}}{C_{f j} \cdot x_{i j} \cdot t}
$$

where $N S R_{i j}$ is the NSR for the $i^{\text {th }}$ sample of species $j ; C_{f j}$ and $B$ are the average sensitivity and background signal of species $j$ during the campaign; $t$ is the time resolution (10 min) of VOC concentrations used in PMF. 
In this study, a total of 225 chemical species (Table S1) were used in the PMF model to quantitatively analyze contributions of likely sources to the VOCs measurements made during the CTT campaign. VOC species with an SNR $\geq 1,0.2<$ $\mathrm{SNR}<1$, and $\mathrm{SNR}<0.2$ were categorized as "strong", "weak", and "bad", respectively. The uncertainties of weak VOC species were doubled, while bad species were removed from the analysis. Figure $\mathrm{S} 3$ shows the change in $\mathrm{Q} / \mathrm{Q}$ expected ratio with the increased number of factors in PMF. The $\mathrm{Q} / \mathrm{Q}_{\text {expected }}$ ratio decreased slowly when the number of factors increased from 5 to 6 . In addition, profiles of two certain factors were highly correlated when the number of factors exceeded 5, resulting in an excessive decomposition of the VOCs measurements. As shown in Figure S4, the VOCs measurements were well reconstructed by a five-factor solution, which was deemed optimal for the PMF analysis in this study.

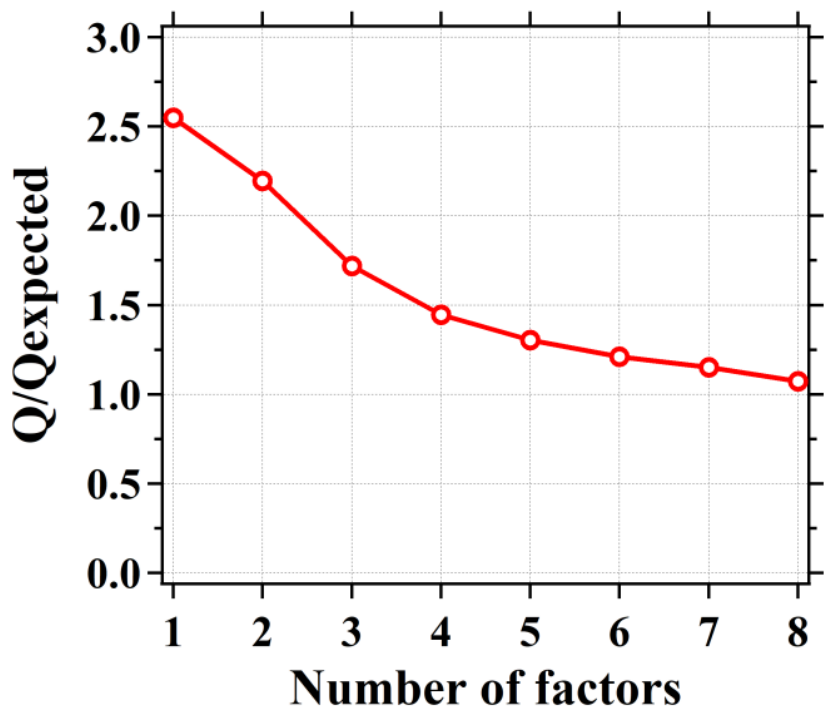

Figure S3. Variation in the ratio of $\mathrm{Q} / \mathrm{Q}_{\text {expected with change in the number of factors for }}$ the PMF analysis.

As shown in Figures 6 and S5, the most prominent composition in factor 1 were OVOC species including acetic acid, formaldehyde, acetone, methanol, acetaldehyde, hydroxyacetone, and formic acid, which contributed to over $70 \%$ of the concentration of the factor. These OVOC species with low molecular weights generally have complex sources in urban environments (Hu et al., 2013; Karl et al., 2018; McDonald et al., 2018; Pallavi et al., 2019; Gkatzelis et al., 2021), such as vehicular exhausts, various industrial 
processes, biogenic emissions, as well as the oxidative degradation products of hydrocarbons. The diurnal profile of factor 1 increased between LT 09:00-14:00 and continuously decreased from LT 14:00 to 08:00 on the next day, which is consistent with the diurnal variation in ozone. Hourly mean contributions of factor 1 were also well correlated with those of ozone $(r=0.75)$, implying strong dependence of factor 1 on sunlight and temperature. As a result, it is highly challenging to identify sources of factor 1 merely relying on its factor profile that does not contain dominant fingerprint species of specific emission sources. Therefore, factor 1 was assigned to the daytimemixed source, predominantly including contributions from biogenic emissions and photooxidation products of various VOC species.

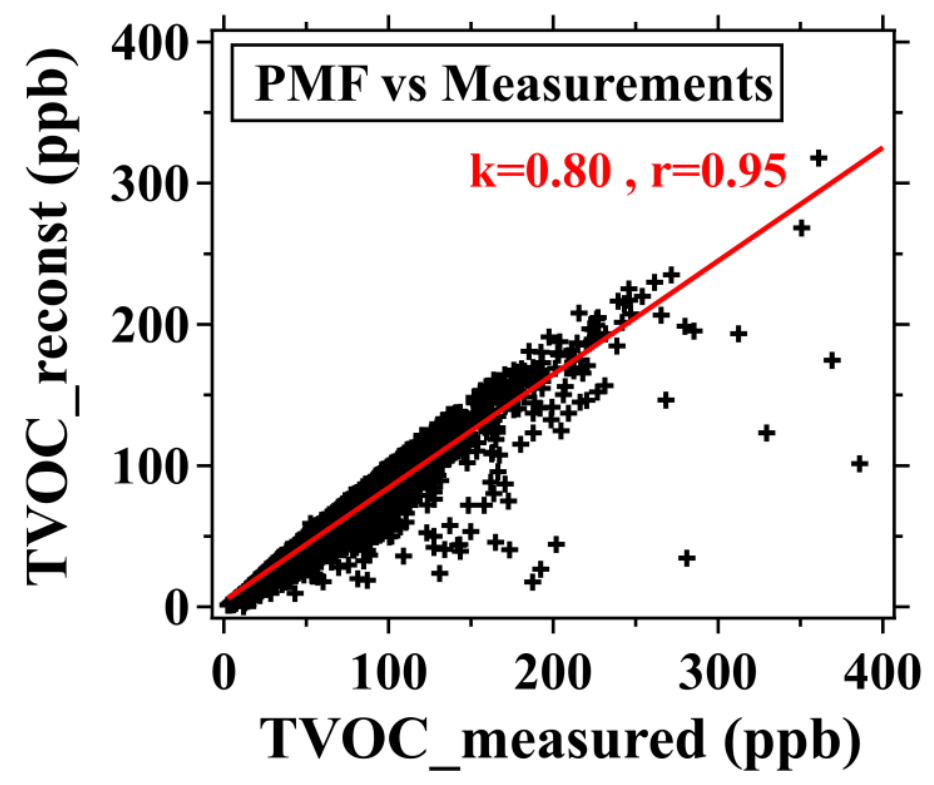

Figure S4. Scatter plots of PMF-reconstructed TVOC concentrations (TVOC_reconst) versus measured TVOC concentrations (TVOC_measured).

Factor 2 was characterized by a high percentage (72\%) of ethanol and exhibited a similar diurnal pattern to ethanol. These results confirm that contributions of factor 2 were closely associated with visitor-related emissions. In addition, contributions of factor 2 had the narrowest autocorrelation profile (Figure 6), implying that they were contributed by the most local emission sources. Thus, factor 2 was assigned to the visitor-related source, predominantly including contributions from human breath and volatilization of personal care products. It should be noted that large fractions of ethanol 
emitted from personal care products were generally attributed to the VCP source in previous studies (McDonald et al., 2018; Gkatzelis et al., 2021). This is correct when the observation site was not affected by intensive emissions from a known source such as visitors at the $450-\mathrm{m}$ platform. The visitor-related source was resolved in PMF to separate contributions of VCPs from those emitted by visitors.

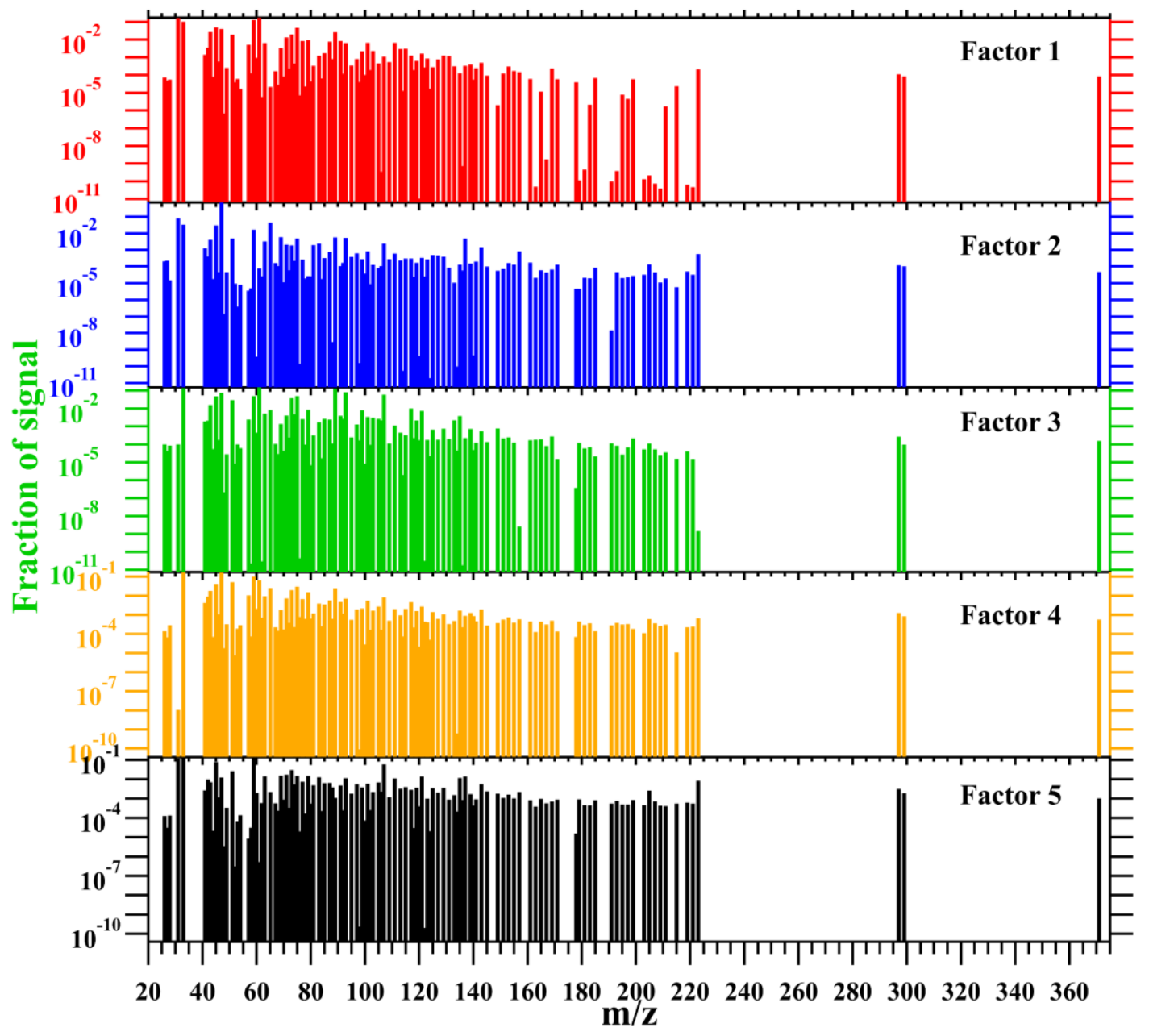

Figure S5. Factor profiles (covering the full range of the mass spectra) of the five factors resolved by the PMF model.

Factor 3 was primarily composed of acetic acid, methanol, ethyl acetate, toluene, ethanol, and C8 aromatics, contributing to over $62 \%$ of the concentration of the factor. The diurnal profile of factor 3 was highly consistent with those of aromatics, such as toluene, exhibiting lower mixing ratios during the daytime with a minimum occurring at LT 14:00. Factor 3 explained over $90 \%$ and $70 \%$ of the variations in toluene and C8 aromatics, respectively, during the campaign. As reported in the literature (Zhang et al., 
2013; Liu et al., 2016; Pallavi et al., 2019), aromatics are known components of vehicular exhausts, solvent usage, industrial raw materials, and emissions of various industrial processes. However, the PMF solution can not explicitly separate these sources in this study due to the lack of measurements for alkanes and low-carbon alkenes. In addition, factor 3 was less affected by visitor-related emissions due to its lower contributions during the opening hours of the 450-m platform on non-working days. Therefore, factor 3 was assigned to the vehicular+industrial source, predominantly including contributions from vehicular exhausts and emissions of various industrial processes.

Methanol, ethanol, acetone, and acetic acid were the most abundant species in factor 4 , which contributed to over $51 \%$ of the concentration of the factor. The diurnal profile of factor 4 exhibited insignificant variability with slight increases between LT 08:00-13:00. Only a small fraction $(<5 \%)$ of reactive chemical species such as aromatics were attributed to this factor. Factor 4 was also less affected by visitor-related emissions due to its lower contributions during the opening hours of the 450-m platform on non-working days. To further explore likely sources of factor 4, we also conducted a cluster analysis of 72-h backward trajectories, as detailed in the SI file. As shown in Figure S7, contributions of factor 4 accounted for $13 \%$ of the TVOC mixing ratio when affected by continental airflows, but only accounted for $3 \%$ when affected by marine airflows. However, contributions of the other factors displayed relatively weaker variations in different clusters of the backward trajectories. These results confirm that contributions of factor 4 had a strong dependence on wind direction and were highly associated with advection transport from nearby or distant cities. In addition, contributions of factor 4 had the flattest autocorrelation profile (Figure 6), indicating that it was less affected by local emissions. Therefore, factor 4 was assigned to the regional transport source, predominantly including contributions from advection transport of aged air masses.

Methanol, acetone, formaldehyde, and acetaldehyde were the most prominent species in factor 5 , which contributed to over $46 \%$ of the concentration of the factor. In addition to contributions from secondary formation and vehicular exhausts, these 
OVOC species were also known components of VCPs (McDonald et al., 2018; Gkatzelis et al., 2021). As shown in Figure 6, the diurnal profile of factor 5 exhibited peak values between LT 08:00-09:00, during which personal care products were extensively used and vehicular exhausts were extensively emitted. Therefore, the diurnal variation pattern of factor 5 was similar to NOx (Figure 4), which is a typical tracer of vehicular exhausts in urban areas. The diurnal profile of factor 5 was also consistent with that of D5-siloxane, which is a key tracer for VCPs in urban environments (Tang et al., 2015; Gkatzelis et al., 2021). As shown in Figure 8, factor 5 contributed to a large fraction (45\%) of D5-siloxane and had an ignorable contribution to toluene, confirming predominant contributions of VCPs, rather than vehicular exhausts, in factor 5. Thus, factor 5 was assigned to the VCP-dominated source. 


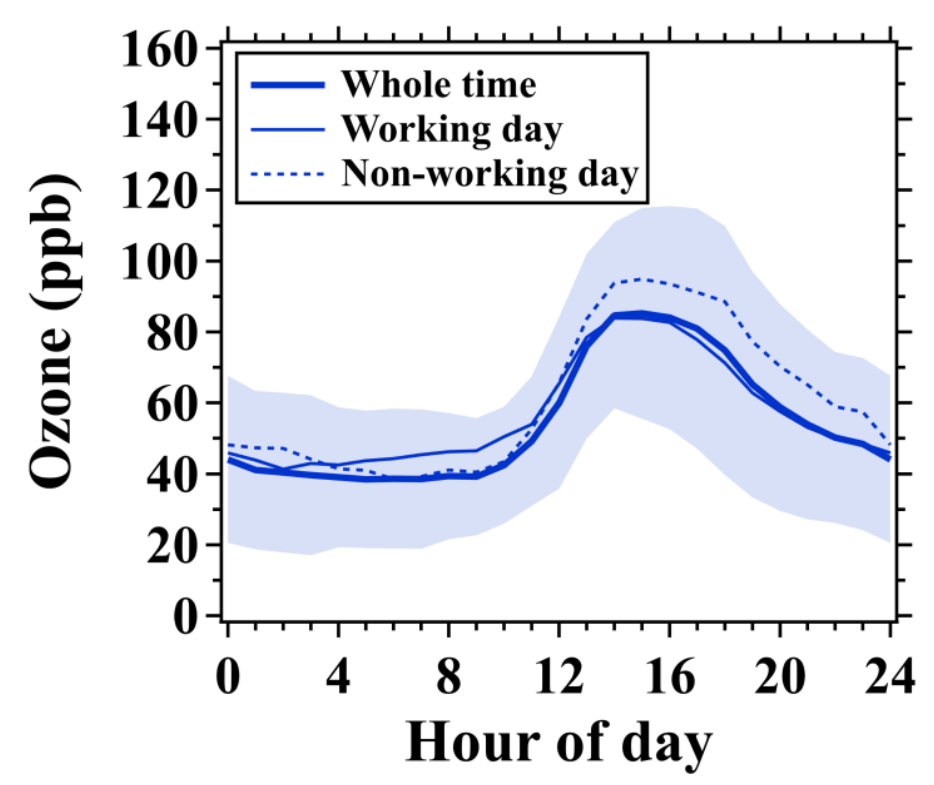

Figure S6. Diurnal variations in ozone mixing ratios measured at $488 \mathrm{~m}$. Thick blue solid lines and shaded areas represent averages and standard deviations during the CTT campaign (August 18-November 05, 2020); Thin blue solid and dashed lines represent averages in working days and non-working (including weekends and public holidays) days, respectively. 


\section{Cluster analysis of backward trajectories}

Backward trajectories (72 h) of air masses at an arrival altitude of $450 \mathrm{~m}$ over the CTT site were calculated for each hour during the campaign using the HYSPLIT Trajectory Model in MeteoInfo software (v 3.0.2). The backward trajectories were calculated based on meteorological data (one-degree resolution, global) from the GDAS system (ftp://ftp.arl.noaa.gov/pub/archives/gdas1) (Stein et al., 2015). Cluster analysis of the backward trajectories was performed in the MeteoInfo software using the Euclidean distance method (Wang, 2014), as shown in Figure S7.

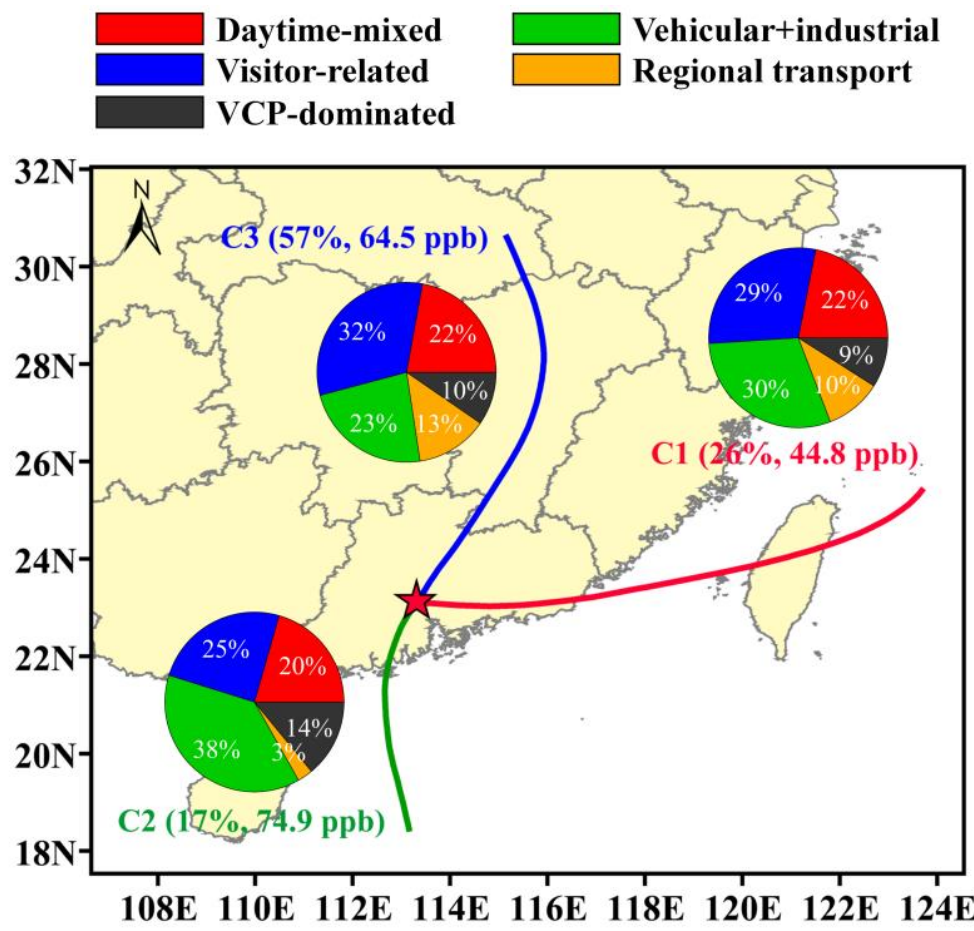

Figure S7. Cluster analysis of 72-h backward trajectories calculated for 24 hours on each day at an arrival altitude of $450 \mathrm{~m}$ above ground level at the CTT site. The red star indicates the CTT site. Pie charts indicate the average contributions of the five PMF factors in each cluster. The two digits in each parenthesis refer to the faction of the trajectories and the average TVOC concentration, respectively, in each cluster. C1, C2, and $\mathrm{C} 3$ indicate the three clusters of the trajectories, respectively.

Contributions of the five factors displayed strong variations during the campaign. For example, contributions of the visitor-related and regional transport sources 
significantly increased from October 3 to November 4, along with prominent decreases in contributions of the vehicular+industrial source. It indicates that contributions of different sources had strong dependences on wind direction. As shown in Figure S7, the three clusters of air masses in this study are similar to those reported in the literature (Xia et al., 2021). Cluster 1, accounting for $26 \%$ of the backward trajectories, represents air masses that predominantly originated from the East China Sea and traveled over coastal regions before reaching the CTT site. Cluster 2, accounting for $17 \%$ of the backward trajectories, represents air masses that predominantly originated from the South China Sea and traveled over the southwest PRD region before reaching the CTT site. Cluster 3, accounting for $57 \%$ of the backward trajectories, represents air masses that predominantly originated from inland regions.

The average TVOC mixing ratios in the three clusters were 44.8, 74.9, and 64.5 ppb, respectively. Cluster 2 was characterized by the highest TVOC mixing ratios during the campaign with the largest contributions (38\%) from the vehicular+industrial source. In addition, the regional transport source only contributed to $3 \%$ of TVOC mixing ratios in cluster 2 due to the marine origins of air masses. It implies that the measured TVOC mixing ratios were more contributed by local emissions with the higher fractions of reactive VOC species (such as aromatic species) when southwesterly winds prevailed over the PRD region, leading to a frequent occurrence of extremely high ozone mixing ratios. By contrast, contribution fractions of the vehicular+industrial source decreased to $30 \%$ and $23 \%$ in clusters 1 and 3 , respectively, accompanied by significant increases in contributions of the regional transport source. Therefore, transport processes, driven by aged air masses from continental or coastal regions, were also important sources, contributing to over $10 \%$ of TVOCs mixing ratios. Contribution fractions of the daytime-mixed source slightly varied in the range of 20-22\% among the three clusters of air masses, indicating a weaker wind direction dependence of the daytime-mixed source in comparison to other sources. The VCP-dominated source accounted for the highest fraction (14\%) of TVOC mixing ratios in cluster 2 and comparable fractions in clusters $1(9 \%)$ and $3(10 \%)$, further confirming predominant contributions of local anthropogenic emissions when affected by southeasterly air flows. 
The visitor-related source contributed to $32 \%$ and $29 \%$ of TVOC mixing ratios in clusters 1 and 3 , respectively, which was significantly greater than in cluster 1 . The increased percentages of the visitor-related source in clusters 1 and 3 could be predominantly attributed to reduced contributions from the vehicular+industrial source. In addition, clusters 1 and 3 mainly occurred in the middle and late periods of the campaign, during which the 450-m platform took on more visitors with the successful control of the COVID-19 in China. Therefore, the larger numbers of visitors in clusters 1 and 3 were another important reason for the increased percentages of the visitorrelated source in TVOC mixing ratios. 

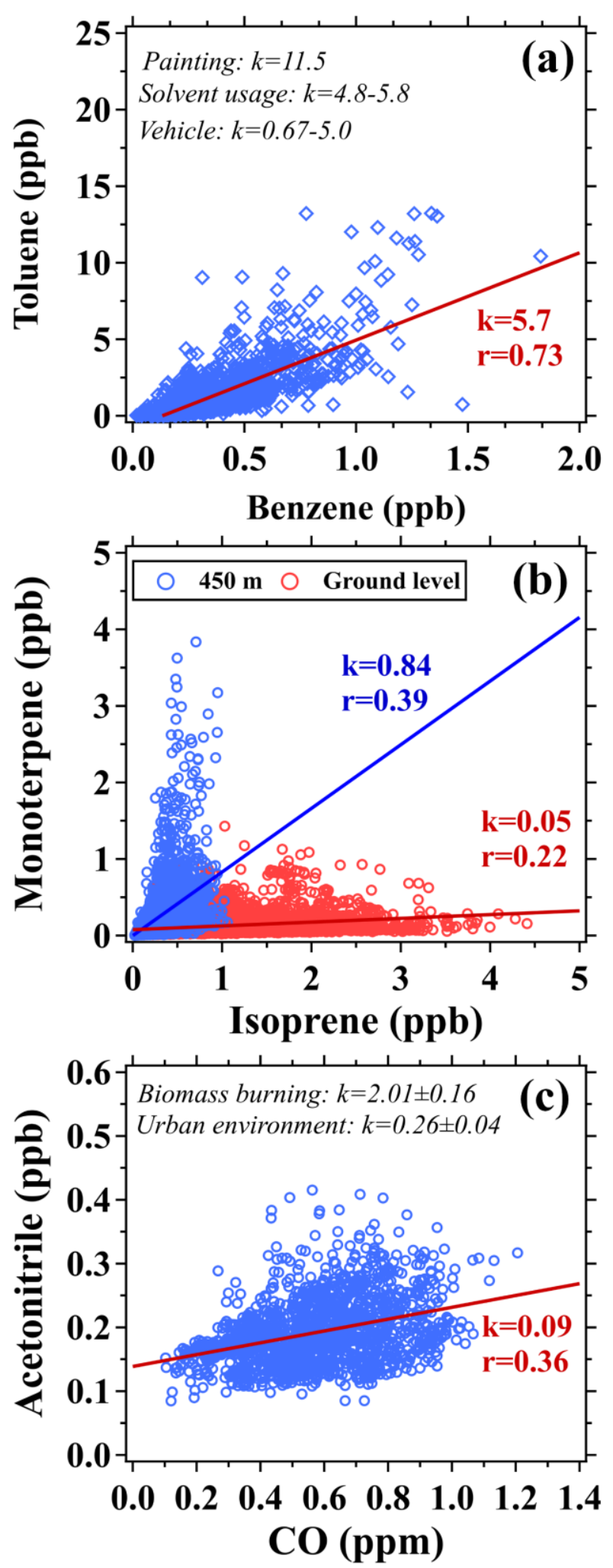

Figure S8. Scatter plots of (a) toluene versus benzene mixing ratios, (b) monoterpene versus isoprene mixing ratios, and (c) acetonitrile versus $\mathrm{CO}$ mixing ratios; In panel (b), only the measurements in the daytime (LT 08:00-18:00) were used. 


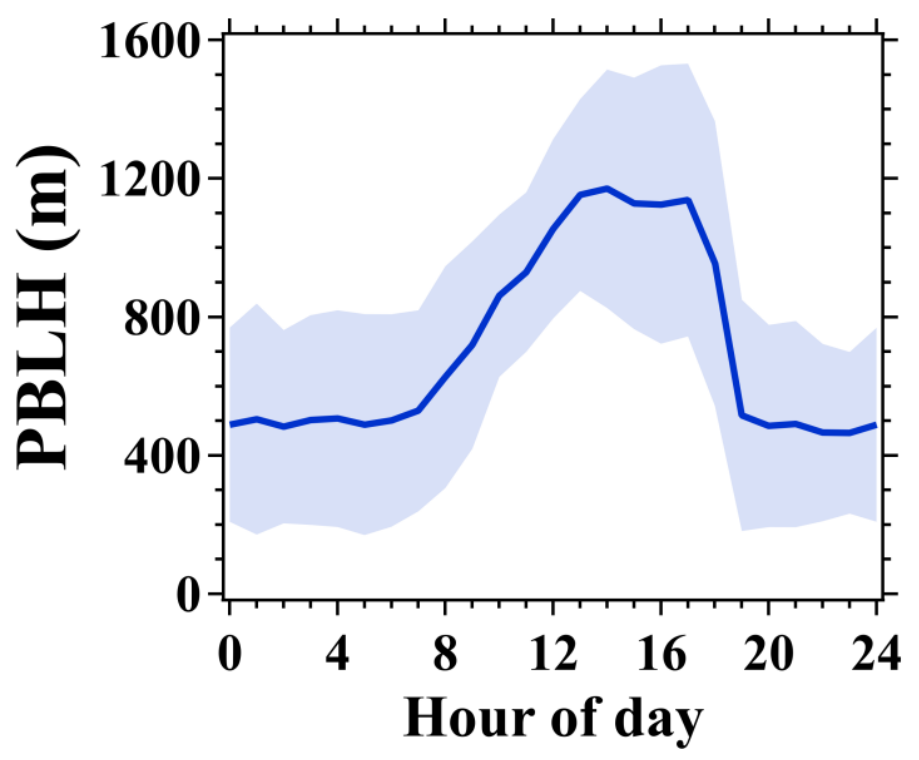

Figure S9. Diurnal variation in planetary boundary layer height (PBLH). Blue solid lines and shaded areas represent averages and standard deviations, respectively. 


\section{References}

Gkatzelis, G. I., Coggon, M. M., McDonald, B. C., Peischl, J., Gilman, J. B., Aikin, K. C., Robinson, M. A., Canonaco, F., Prevot, A. S. H., Trainer, M., and Warneke, C.: Observations Confirm that Volatile Chemical Products Are a Major Source of Petrochemical Emissions in U.S. Cities, Environ Sci Technol, https://doi.org/10.1021/acs.est.0c05471, 2021.

Hu, L., Millet, D. B., Kim, S. Y., Wells, K. C., Griffis, T. J., Fischer, E. V., Helmig, D., Hueber, J., and Curtis, A. J.: North American acetone sources determined from tall tower measurements and inverse modeling, Atmos. Chem. Phys., 13, 3379-3392, https://doi.org/10.5194/acp-13-3379-2013, 2013.

Karl, T., Striednig, M., Graus, M., Hammerle, A., and Wohlfahrt, G.: Urban flux measurements reveal a large pool of oxygenated volatile organic compound emissions, Proceedings of the National Academy of Sciences of the United States of America, 115, 1186-1191, https://doi.org/10.1073/pnas.1714715115, 2018.

Liu, B., Liang, D., Yang, J., Dai, Q., Bi, X., Feng, Y., Yuan, J., Xiao, Z., Zhang, Y., and $\mathrm{Xu}, \mathrm{H} .:$ Characterization and source apportionment of volatile organic compounds based on 1-year of observational data in Tianjin, China, Environ Pollut, 218, 757 769, https://doi.org/10.1016/j.envpol.2016.07.072, 2016.

McDonald, B. C., de Gouw, J. A., Gilman, J. B., Jathar, S. H., Akherati, A., Cappa, C. D., Jimenez, J. L., Lee-Taylor, J., Hayes, P. L., McKeen, S. A., Cui, Y. Y., Kim, S.W., Gentner, D. R., Isaacman-VanWertz, G., Goldstein, A. H., Harley, R. A., Frost, G. J., Roberts, J. M., Ryerson, T. B., and Trainer, M.: Volatile chemical products emerging as largest petrochemical source of urban organic emissions, Science, 359, 760, https://doi.org/10.1126/science.aaq0524, 2018.

Paatero, P., and Tapper, U.: Positive matrix factorization: A non-negative factor model with optimal utilization of error estimates of data values, Environmetrics, 5, 111-126, https://doi.org/10.1002/env.3170050203, 1994.

Paatero, P., Eberly, S., Brown, S. G., and Norris, G. A.: Methods for estimating uncertainty in factor analytic solutions, Atmos. Meas. Tech., 7, 781-797, https://doi.org/10.5194/amt-7-781-2014, 2014.

Pallavi, Sinha, B., and Sinha, V.: Source apportionment of volatile organic compounds in the northwest Indo-Gangetic Plain using a positive matrix factorization model, Atmos. Chem. Phys., 19, 15467-15482, https://doi.org/10.5194/acp-19-15467-2019, 2019.

Stein, A. F., Draxler, R. R., Rolph, G. D., Stunder, B. J. B., Cohen, M. D., and Ngan, F.: NOAA'S HYSPLIT ATMOSPHERIC TRANSPORT AND DISPERSION MODELING SYSTEM, B Am Meteorol Soc, 96, 2059-2077, https://doi.org/10.1175/bams-d-14-00110.1, 2015.

Tang, X., Misztal, P. K., Nazaroff, W. W., and Goldstein, A. H.: Siloxanes Are the Most Abundant Volatile Organic Compound Emitted from Engineering Students in a Classroom, Environmental Science \& Technology Letters, 2, 303-307, https://doi.org/10.1021/acs.estlett.5b00256, 2015. 
Wang, Y. Q.: MeteoInfo: GIS software for meteorological data visualization and analysis, Meteorol Appl, 21, 360-368, https://doi.org/10.1002/met.1345, 2014.

Xia, S.-Y., Wang, C., Zhu, B., Chen, X., Feng, N., Yu, G.-H., and Huang, X.-F.: Longterm observations of oxygenated volatile organic compounds (OVOCs) in an urban atmosphere in southern China, 2014-2019, Environ Pollut, 270, 116301, https://doi.org/10.1016/j.envpol.2020.116301, 2021.

Zhang, Y., Wang, X., Barletta, B., Simpson, I. J., Blake, D. R., Fu, X., Zhang, Z., He, Q., Liu, T., Zhao, X., and Ding, X.: Source attributions of hazardous aromatic hydrocarbons in urban, suburban and rural areas in the Pearl River Delta (PRD) region, J Hazard Mater, 250-251, 403-411, https://doi.org/10.1016/j.jhazmat.2013.02.023, 2013. 